\title{
Aesthetic and functional rehabilitation in a patient with anterior skeletal open bite using lithium dissilicate glass-reinforced ceramic: a case report
}

\author{
Reabilitação estética e funcional em paciente com mordida aberta esquelética utilizando cerâmica \\ reforçada por dissilicato de lítio: relato de caso clínico \\ Rehabilitación estética y funcional en paciente con mordida abierta esquelética utilizando cerámica \\ reforzada con litio disilicado: reporte de caso clínico
}

Karen Katlein Dolenkei

ORCID: https://orcid.org/0000-0003-3354-9190 Federal University of Uberlândia, Brazil E-mail: karendolenkei@hotmail.com

Lucas do Nascimento Tavares

ORCID: https://orcid.org/0000-0002-9600-8028 Federal University of Uberlândia, Brazil E-mail: lucastavaresodonto@gmail.com

Denildo de Magalhães

ORCID: https://orcid.org/0000-0003-1152-5841 Federal University of Uberlândia, Brazil E-mail: denildo@ufu.br

Luís Henrique Araújo Raposo

ORCID: https://orcid.org/0000-0003-2726-9133 Federal University of Uberlândia, Brazil E-mail: raposo@ufu.br

\begin{abstract}
The aim of this clinical report is to present the replacement of unsatisfactory metal-ceramic crowns of elements 12 , 11, 21 and 22, by lithium disilicate glass-reinforced ceramic crowns in a patient with skeletal anterior open bite. A patient sought care at the Dental Hospital at the School of Dentistry of UFU, complaining of odor between the metalceramic crowns of the antero-superior teeth. After clinical and radiographic examination, invasion of the biological space was noticed, surgery was indicated in order to restore the biological space. After healing, the pre-existing cast metal posts were masked using an opaque composite resin and the teeth were reprepared for full all-ceramic crowns. Impressions were taken in two steps, using PVS associated to retraction cords. The ceramic copings were obtained in lithium disilicate ceramic, and the veneering was performed by stratification. After testing the ceramics crowns in relation to, fit, function and aesthetic results, cementation was completed using modified absolute isolation, followed by prophylaxis of preparations with pumice and saline, surface treatment of the ceramic restorations and luting using self-adhesive resin cement. Finally, an occlusal splint was produced to control the effects of bruxism and orofacial pain symptoms. The anterior open skeletal bite was a challenging factor for the rehabilitation of this patient; however, one must consider the entire process that the patient would undergo if choosing for orthognathic surgery, and the patient should be aware of the case limitations. In addition, the use of lithium disilicate glass-reinforced ceramics proved the versatility of this material for anterior aesthetic restorations.
\end{abstract}

Keywords: Ceramics; Dental prosthesis; Open bite.

\section{Resumo}

O objetivo deste relato de caso foi demonstrar a substituição de coroas metalocerâmicas insatisfatórias nos elementos $12,11,21$ e 22, por coroas cerâmicas reforçadas por dissilicato de lítio em paciente com mordida aberta esquelética anterior. Paciente procurou atendimento no Hospital Odontológico da Faculdade de Odontologia da UFU se queixando de odor entre as coroas instaladas nos dentes anteriores. Após exame clínico e radiográfico foi constatado invasão de espaço biológico e a necessidade de cirurgia de aumento de coroa clínica. Após cicatrização, os núcleos metálicos pré-existentes foram mascarados com resina composta opaca e repreparados. Foi realizado moldagem de trabalho em dois passos, utilizando silicone por adição associado a fios afastadores. Os copings cerâmicos foram confeccionados em dissilicato de lítio e cerâmica de cobertura foi aplicada pela técnica de estratificação. Após realizar a prova das cerâmicas em relação a adaptação, função e estética, a cimentação das coroas foi realizada utilizando isolamento absoluto modificado, seguido de profilaxia com pedra pomes e soro fisiológico, tratamento da superfície interna das peças cerâmicas e cimentação empregando cimento resinoso autoadesivo. Por último, foi confeccionada placa oclusal estabilizadora para controle dos efeitos do bruxismo e da dor orofacial. A mordida aberta esquelética foi 
um desafio para a substituição das restaurações indiretas nesse caso, porém, deve-se levar em consideração todos os procedimentos necessários caso a paciente optasse pela cirurgia ortognática, devendo a mesma estar ciente das limitações do caso. Além disso, a utilização de cerâmicas reforçadas por dissilicato de lítio comprova a sua versatilidade para restaurações estéticas anteriores.

Palavras-chave: Cerâmica dental; Prótese dentária; Mordida aberta.

\section{Resumen}

El objetivo de este caso clínico es demonstrar la sustitución de coronas metal-cerámicas insatisfactorias de los elementos 12, 11, 21 y 22, por coronas cerámicas reforzadas con disilicato de litio en paciente con mordida abierta esquelética anterior. Paciente acudió al Hospital Odontológico de la Facultad de Odontología de la UFU quejándose de mal olor entre las coronas instaladas en dientes anteriores. Tras examen clínico y radiográfico, fue conprobado invasión del espacio biológico y la necesidad de una cirugía de aumento de corona clínica. Después de la curación, los núcleos metálicos preexistentes fueran enmascarados con resina compuesta opaco y repreparados. Fue empezado el moldeo en dos pasos, utilizando silicone por adicion y fios retractores. Los copings fueram hecho en disilicato de lítio y fueran recobiertas por cerámica por la tecnica de estratificacion. Después de probar la cerámica para la adaptación, función y resultados estéticos, se realizó la cementación con aislamiento absoluto modificado, seguido de profilaxis con piedra pómez y solución salina, tratamiento superficial interno de la piezas cerámicas y la cementación con cemento resinoso autoadesivo. Finalmente, se colocó una placa estabilizadora oclusal para controlar los efectos del bruxismo y su dolor orofacial. La mordida esquelética abierta fue un reto em esto caso clínico, sin embargo, se debe tener en cuenta todo el proceso que atravesaría si se optara por la cirugía ortognática, y lo paciente se debe tener en cuenta las limitaciones del caso. Además, el uso de cerámicas reforzadas con disilicato de litio demuestra su versatilidad para restauraciones anteriores.

Palabras clave: Cerámica dental; Prótesis dental; Mordida abierta.

\section{Introduction}

Anterior open bite (AOB) was first conceptualized in 1842, defined as the presence of a negative overbite between the upper and lower incisors, while the posterior teeth are in total occlusion (Keerthana, Thulasiram, \& Kannan, 2020). AOB is among the malocclusions with the greatest aesthetic-functional interference and can be broadly classified as dental or skeletal open bite (Burford \& Noar, 2003).

Skeletal open bite is usually more severe, in some cases, and there may only be contact in the last molars. Its main etiological factor is the unproportional growth of the bone bases, disproportioning several facial bones, leading the patient to a long face profile, in addition to the presence of deleterious habits, such as non-nutritive sucking and abnormal tongue function (Proffit, 2002; Burford \& Noar, 2003). Early AOB treatment allows for a better prognosis and avoids more complex surgical interventions (Maciel \& Leite, 2005).

Over the last decades, the use of ceramic materials in several areas of dentistry has increased and, consequently, the number of researches on the chemical properties and manufacturing techniques on the use of these materials has grown (Willard \& Chu, 2018). The current use of ceramics in dentistry is wide and stems from a long historical background (Anusavice, 2013, Raposo et al., 2014; Butt, Thanabalan, Ayub, \& Bourne, 2019). Dental ceramics are considered a good restorative option for oral rehabilitations, due to their mechanical, physical, and aesthetic properties which are adequate for several clinical situations (Silva et al., 2017, Zhang et al., 2019). Its clinical indication was initially restricted to anterior regions, but after modifications on the composition, it was possible to associate important factors such as function, strength and aesthetics, allowing dental ceramics to be used also in the posterior regions (Song, Ren, \& Yin, 2016; Andrade, Silva, Vasconcelos, \& Vasconcelos, 2017).

Dental ceramics can be classified according to type, composition/content, clinical indication and sintering temperature (Raposo et al., 2014). The chemical composition of ceramics is extremely important to define their applications. For a long time, feldspathic ceramics were the only option used in dental restorations, until the 1960s. As a versatile material, it is known for its polymorphism, despite its low tensile and flexural strength, ranging from 60 to $70 \mathrm{MPa}$. In addition, it demonstrates limited capacity for stress dissipation, allowing the accumulation of these at the ends and cracks of the restoration (Gomes, Assunção, Rocha, \& Santos, 2008, Andrade et al., 2017). Thus, its indication was limited only to anterior unitary all-ceramic 
crowns or as veneering ceramic over metallic frames to general applications (Amoroso et al., 2012).

In the early 90's, IPS Empress was introduced on the market aiming to improve the resistance of feldspathic ceramics. For this, the amount of leucite crystals was increased in the composition of the material and, therefore, an improvement of 30$35 \%$ was observed in flexural strength, and fracture resistance changed from 97 to $180 \mathrm{MPa}$ (Gomes et al., 2008; Martins et al., 2010). Basically, the reinforcement in the feldspathic ceramics was responsible for reducing the propagation of cracks and microfractures, important points for better clinical performance. This material is indicated for rehabilitations such as inlays, onlays, veneers, anterior and posterior unitary crowns, and it is contraindicated for fixed partial bridges (Conceição \& Sphor, 2005).

Thus, in 1998, the IPS Empress 2 system was introduced on the market by Ivoclar Vivadent (Garcia, Consani, Cruz, \& Souza, 2011; Lien et al., 2015) with the intention of extending the indication of glass-reinforced ceramics. In 2006, the E.max Press (Ivoclar Vivadent, Schaan, Liechtenstein) emerged commercially as the new generation of pressable ceramics, with better results in their mechanical and optical properties (Kang, Chang, \& Song, 2013).

Among the ceramic systems, lithium disilicate glass-reinforced ceramic $\left(\mathrm{SiO}_{2} \mathrm{Li}_{2} \mathrm{O}\right)$ is indicated for most prostheses that require esthetics and longevity. The flexural strength values of this system range from 300 to $400 \mathrm{MPa}$, due to $60 \%$ to $65 \%$ of its volume being crystals. It has up to seven times more resistance as compared to feldspathic ceramics. In addition, another important feature is the possibility of being milled by CAD/CAM (Computer-Aided Design/Computer-Aided Manufactoring) technology, as was already possible with feldspathic and leucite-reinforced ceramic materials. The possibility of processing ceramics reinforced by lithium disilicate using CAD/CAM systems makes the prosthetic procedures more agile, since this is a very versatile material (Raposo et al., 2014; Andrade et al., 2017).

Other important characteristics for the clinical success of this material are named, such as good translucency, color stability, low thermal conduction, biocompatibility, marginal adaptation, and resistance to abrasion (Conceição \& Sphor, 2005; Kassardjian et al., 2016; Andrade et al., 2017). Thus, the increase in fracture resistance results in longevity and, therefore, can be indicated for making inlays, onlays, laminates, copings/infrastructures, single crowns, and three-element fixed partial dentures up to the 2nd premolar region (Amoroso et al., 2012; Carvalho et al., 2012). However, the initial investment required for using this system may be high and failure in their production can lead to micro fractures, which makes the ceramic fragile and compromises its clinical performance (Martins et al., 2010; Raposo et al., 2014).

Thus, the main objective of this case report is to present a case with replacement of metal-ceramic crowns of elements $12,11,21$ and 22 by lithium disilicate glass-reinforced ceramic crowns in a patient with skeletal anterior open bite.

\section{Methodology}

This paper reports a clinical case on a functional and aesthetic rehabilitation using ceramics reinforced by lithium disilicate in the region of teeth 12 to 22 , in a patient with the presence of an anterior open bite. In order to explore its particularity, and thus, show a more detailed analysis of the case, so that it is possible to contribute to the readers. The case description refers to the qualitative and exploratory method (Estrela, 2018). The patient was informed about all the information regarding the study through the Informed Consent Term (FICF) and the authorization of the procedure and publication of the case occurred by signing this document.

\section{Clinical case Report}

A 55-year-old female patient sought care at the Dental Hospital at the School of Dentistry, Federal University of Uberlândia, with the main complaint regarding bad breath and odor between the metal-ceramic crowns of the antero-superior teeth. On the clinical examination, misfits were found in the margins of the crowns, associated with invasion of the biological 
space and gingival recession with exposure of the metallic structure (Figure 1).

Figure 1. A. Initial front view, gingival recession with exposure of the metallic structure of the crowns 12, 21 and 22; B. Side view. Font: Personal archive.

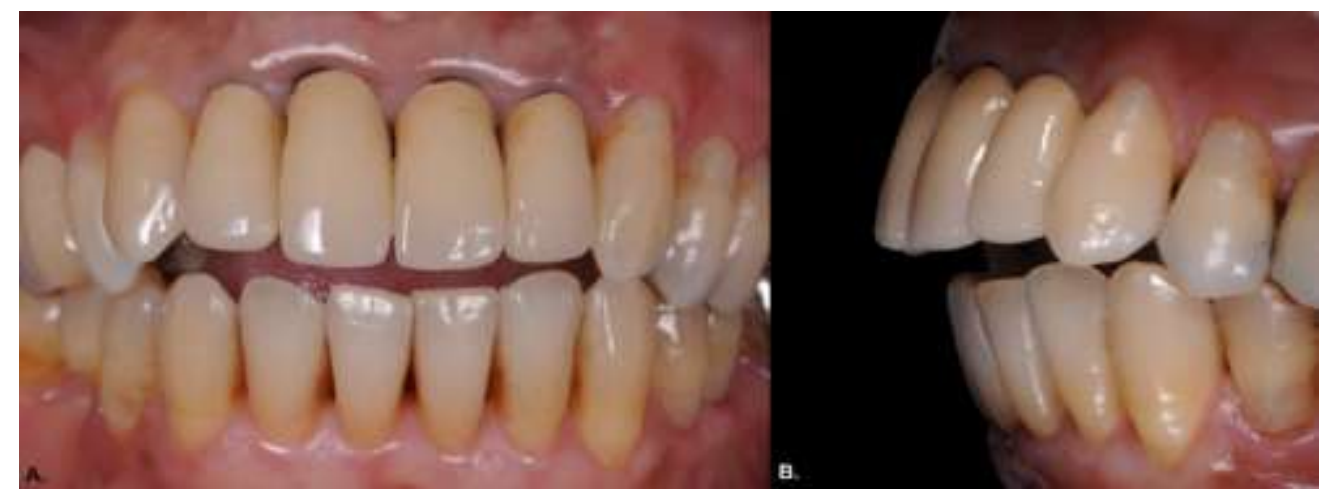

Source: Authors.

From the occlusal examination, it was possible to observe that the patient had skeletal anterior open bite. This fact may be indicative for orthognathic surgery, but the patient rejected the surgical procedure. The patient presented a long, narrow dental arch, with anterior roots very close and a thin gingival profile. She reported that her crowns were installed approximately 5 years ago, and all the four elements had cast metal posts. After radiographic examination, the patient was proposed to undergo crown-lengthening surgery to increase the clinical crown and to recover the biological space, followed by indirect restorative treatment using lithium disilicate glass-reinforced ceramic crowns due to the mechanical and aesthetic properties of this material.

Thus crown-lengthening surgery was performed to re-establish average $3.0 \mathrm{~mm}$ biological space between the end of the preparation and the top of the bone crest (Figure 2). When there is invasion of the biological space, there is damage to periodontal tissues and the final restoration. In order to have success in restorative treatment, the recovery of the biological space is then fundamental. Additionally, a marked separation of at least $1.0 \mathrm{~mm}$ between the roots was obtained to allow adequate impressions and marginal fit of the crowns.

Figure 2. A. Periodontal probe showing $1.0 \mathrm{~mm}$ between the bone crest and the crown margin; B. Periodontal probe showing $3.0 \mathrm{~mm}$ distance after crown-lengthening. Font: Personal archive.

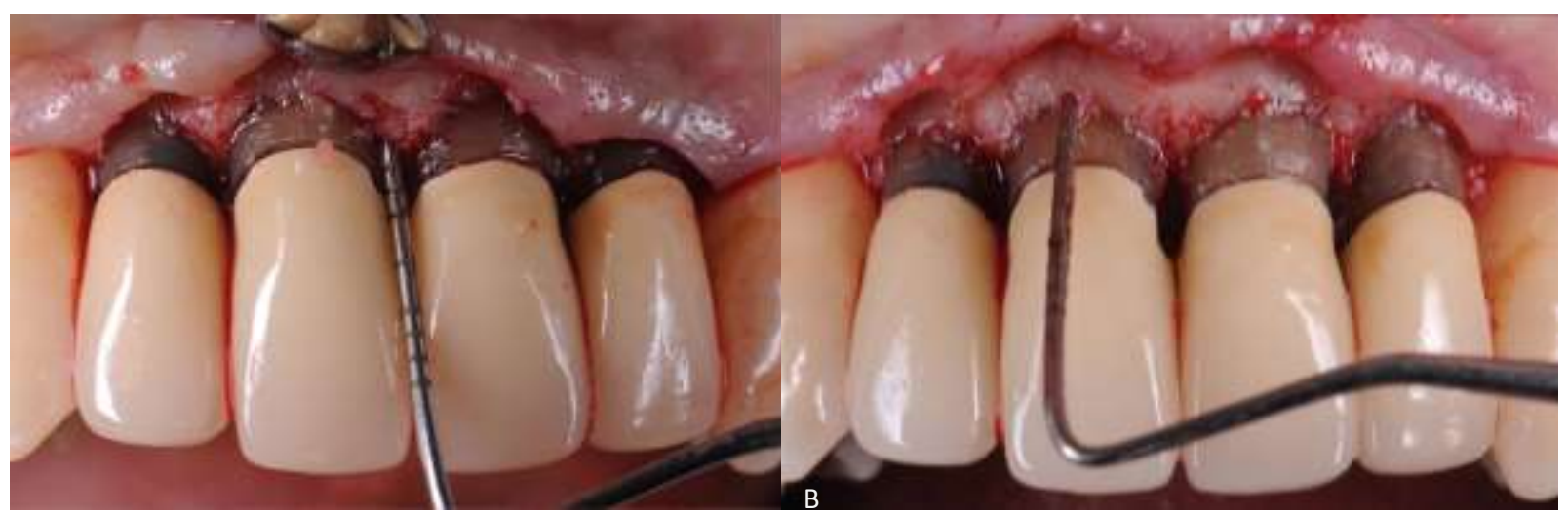

Source: Authors. 
Following 60 days of the periodontal surgery and adequate tissue healing, the metal-ceramic crowns were removed and the cast metal posts of teeth 12 and 21 were accidentally removed. Thus, due to the need to obtain new cast metal posts, cement residues were removed from the canals with using endodontic files and, after that, the root canal was isolated with vaseline and red acrylic resin patterns were moulded (Dencrilay, Dencril, Pirassununga, SP, Brasil) for obtinaining new cast metal posts (Figure 3). After testing the posts, they were luted using zinc phosphate-based cement (SS White, Rio de Janeiro, RJ, Brasil) (Figure 4). The temporary crowns were made by duplicating the previous crowns, employing putty VPS material (President, Coltene, Altstatten, Switzerland) and acrylic resin RA (Vipi Flash®, Pirassununga, SP, Brasil). It was possible to obtain reliable provisional according to the previous dental anatomy of the patient.

Figure 3. A. Molding patterns with red acrylic resin; B. Preparation of resin patterns; C. Adjustments of the cast metal posts; D. Lurting with zinc phosphate-based cement. Font: Personal archive.

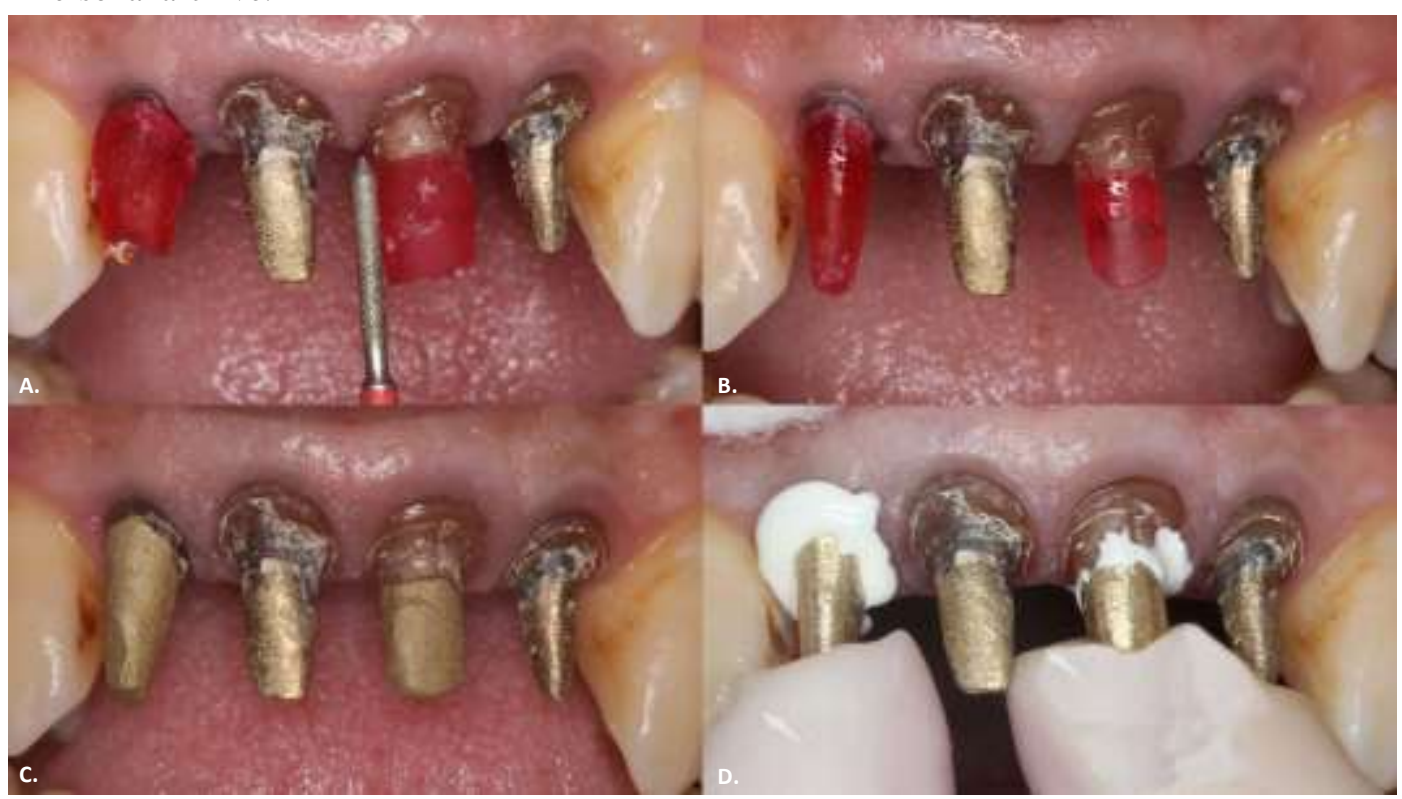

Source: Authors.

Figure 4. A. Cast metal posts; B. After teeth repreparation. Font: Personal archive.

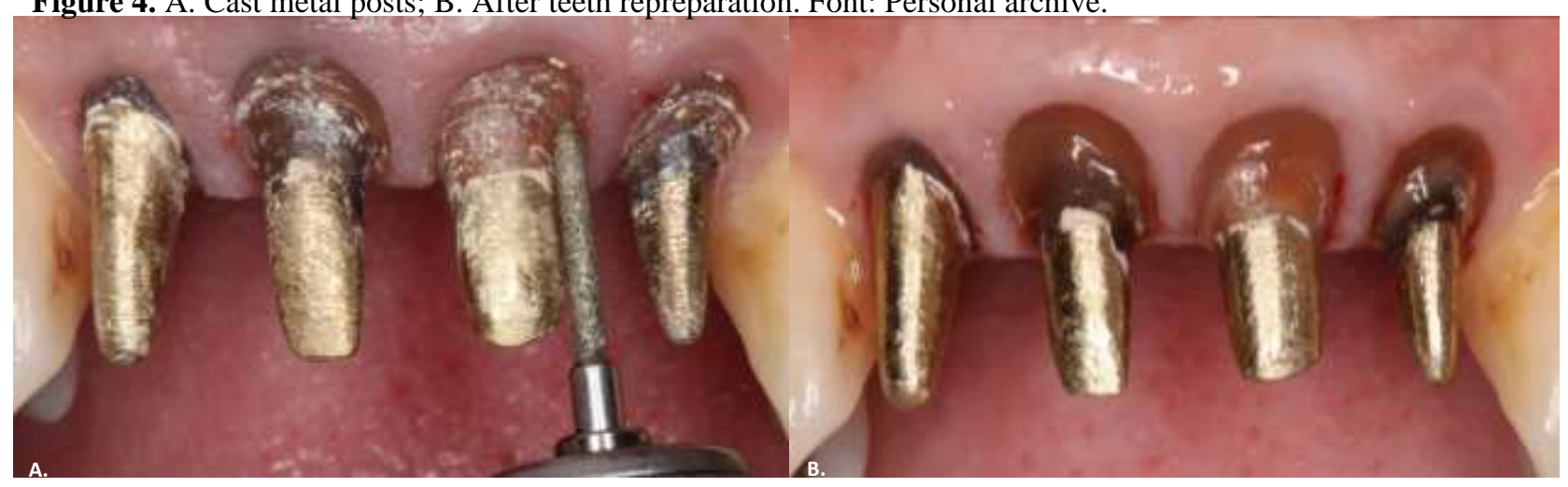

Source: Authors.

To achieve better aesthetics and improve the adhesion of the ceramic crowns, the cast metal posts were reduced and masked with an opaque composite resin. Grooves were made on the metallic surface of the coronary portion, followed by etching with phosphoric acid on the remaining dentin (Condac 37\%, FGM, Joinville, SC) for 15 s, cleansing with water-spray 
and drying with absorbent papers. Then, a universal adhesive system (Adper Single Bond Universal, 3M-ESPE, Saint Paul, MN, USA) was actively applied and light-activated for 20s. The composite resin (Filtek Z350 XT, WD, 3M-ESPE) was inserted over the entire metallic surface and light-cured on all aspects for $40 \mathrm{~s}$. Thus, the metallic material became more discreet (Figure 5). Successively, refining of the preparations was performed to adjust the terminations in deep chanfers to allow the working impressions. First, a \#000 retraction cord (Ultrapack, Ultradent, South Jordan, UT, USA) soaked in hemostatic solution (Hemostop, Dentsply) was inserted into the gingival sulcus, and subsequently, another retraction cord \#00 (Ultrapack) was inserted above the first. After finishing and polishing the preparations, the tray was tested. A two-step impression technique was used, which consists of initially performing a preliminary impression with the VPS putty material (President, Coltene, Altstatten, Suíça), performing slight movements in different directions with the tray before the material is set to create space for the light material. In the second impression, the \#00 retraction cords were removed, the light VPS paste (President, Còltene) was inserted under the gingival tissue and a light jet of air is applied between the preparations, followed by accommodation of the tray the heavy/light material. In this way, it is possible to reproduce the preparation and its margins with good precision (Figure 6). Then, an impression of the lower arch was taken with alginate following the manufacturer's recommendations (Hydrogum, Zhermack, Badia Polesine, Italy). In the same session, the intermaxillary register was taken using acrylic resin (Dencrilay, Dencril) and registration with a face bow with putty VPS for mounting the die cast models in a semi-adjustable articulator. The temporary crowns were adjusted and relined according to the new preparations.

Figure 5. A. Grooves on the coronary surface of the cast metal posts; B. Acid etching for $15 \mathrm{~s}$; C. Insertion of the composite resin; D. Finishing and polishing of composite resin after light curing. Font: Personal archive.

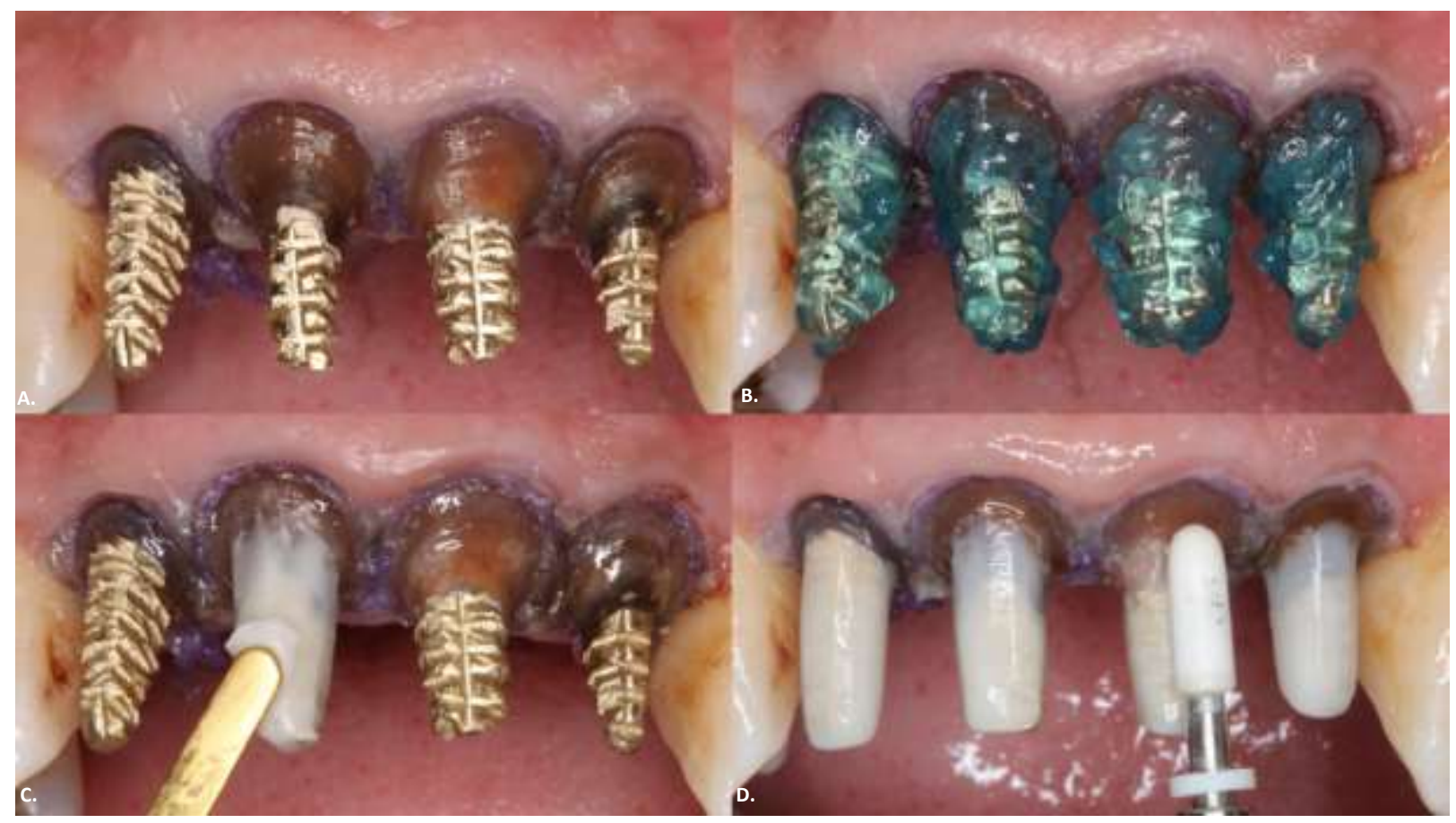

Source: Authors. 
Figure 6. A. Two-step molding, first molding with heavy material and second molding with slurry; B. Reliable reproduction of the preparation. Font: Personal archive.

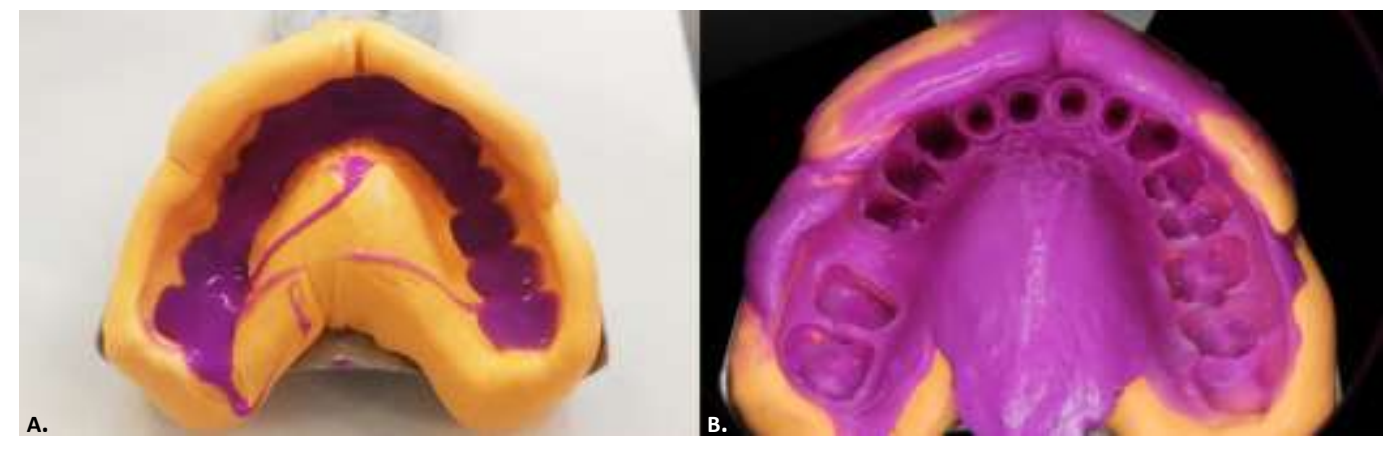

Source: Authors.

From the impressions obtained, die cast models were generated in special high-resistance stone plaster (Durone IV, Dentsply), which were mounted in a semi-adjustable articulator (A7-Plus Padronizado, Bio-Art, São Calos, SP, Brazil), and later the upper model was individualized and die-cut in the region of elements 12, 11, 21 and 22. Each element was die-cut in order to facilitate the visualization of the end of the preparation for carrying out the edge sealing in the waxing. The waxings were included in a refractory material and then, the wax was removed in an oven at high temperature, thus, leaving adequate space to receive the ceramic material. This technique used lithium disilicate glass-reinforced ceramic ingots (IPS e.max, MO-2, Ivoclar Vivadent), which were subjected to high temperature and pressure in a special oven to be injected into the refractory mould, replacing the space left by the wax, forming the ceramic structure. Laboratory adjustments were carried out in the ceramic infrastructures, checking for the presence of efects, the level of material expansion and polishing of the piece.

The ceramic structures initially obtained have not adapted perfectly to the preparations due to processing issues, and it was necessary to use fluid VPS (President, Còltene) to highlight the regions to be adjusted. During adjustments, the structures of teeth 21 and 22 were damaged. Due to this fact, preparations were refined, and new impressions were taken. For having used retractor cords recently, the new impressions were performed using the caps technique in order to not damage the periodontal tissues. The caps were made by duplicating the temporary crowns in an alginate container, placing it with the incisal face visible. Then, the crown was removed, and the space left was filled with acrylic resin, with a slight excess for better handling. After necessary adjustments and relines, the impressions were taken with a polyether-based material (Impregum Soft Regular, 3M-ESPE) (Figure 7). The caps were sent to the laboratory and new ceramic structures were made as described. After checking the ceramic structures on the preparations, an interocclusal register was made with acrylic resin, joining the four structures to keep them in position for subsequent transference impression and colour checking. Thus, a die cast model was obtained to apply the ceramic veneering on the lithium disilicate glass-reinforced ceramic structures. With the die-cast preparations and copings already adjusted, the ceramic sintering process begins. It is applied to a powder and liquid mixture with a brush, distributing the portions according to dental anatomy, dentin, and enamel layers according to color selection recommended in clinical care. Through vibrations, the ceramic is condensed, and with absorbent paper, excess water is removed for greater compaction of the powder. After this process, the crowns are fired in an oven according to the manufacturer's instructions. The adjustments are completed in the laboratory. 
Figure 7. A. Relined cap in position after adjustments; B. Impression of the preparations with a cap and polyether-based material. Font: Personal archive.

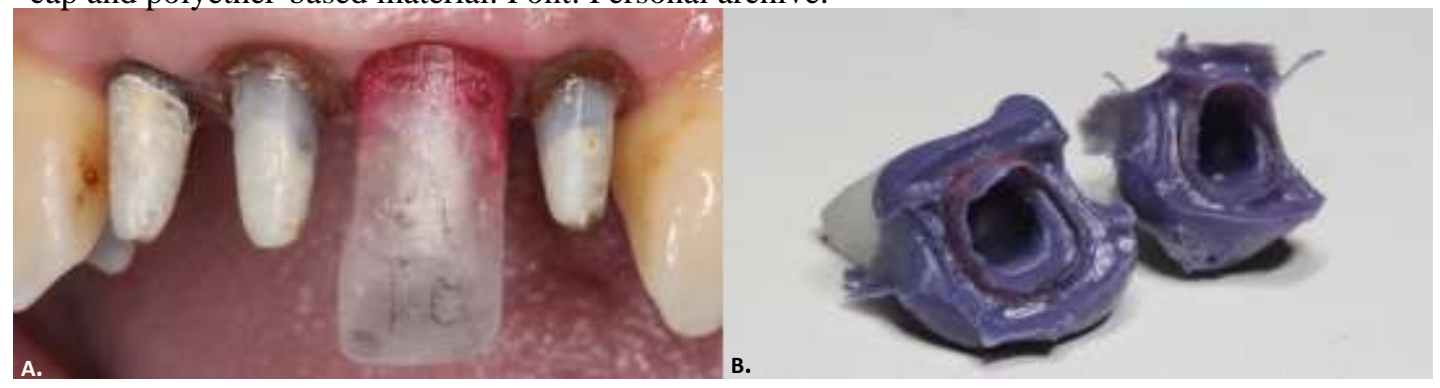

Source: Authors.

Then the provisionals were removed and the preparations sanitized so that there is no trace of temporary luting material. With the parts in position, the proximal contact surfaces were analysed, using occlusal markng film (Accufilm II, Parkel). Too extensive contact can cause hypertrophy of the interdental papilla. With abrasive diamond rubbers, adjustments are made to the pieces with movements from cervical to incisal. At the end, a dental floss test is performed, checking the resistance between the contact surfaces. Then the entire extension of the cervical region was analysed for the presence of periodontal tissue ischemia. Then the functional adjustments were performed, the patient slowly performs maximum intercuspation while the functional contact points are checked. With a strip of occlusal marker, the contact points were checked tooth by tooth for premature contacts or absence of function. In this case, the patient has anterior open bite, and no previous fiunctional contact points were observed. After the adjustments in excursive movements, the shape, contour and colour were analysed. The crowns returned to the laboratory for extrinsic characterization and glazing.

For luting the ceramic restorations, modified absolute isolation was performed, followed by prophylaxis in the preparations using pumice slurry (Figure 8). The surface treatment of the lithium disilicate glass-reinforced ceramic crowns was performed by etching the inner surface with 10\% hydrofluoric acid (Condac Porcelain 10\%, FGM) for 20 seconds. Immediately after, the crowns were submitted to ultrasonic bath with $70 \%$ alcohol for 3 min, followed by water rising and air drying. After vigorous drying, a silane-coupling agent (Prosil, FGM) was actively applied for $20 \mathrm{~s}$ with repetitive movements on the inner surfaces of the crowns, allowing to react for 60 seconds (Figure 9).

Figure 8. A. Modified absolute isolation and prophylaxis of preparations with pumice slurry. Font: Personal archive.

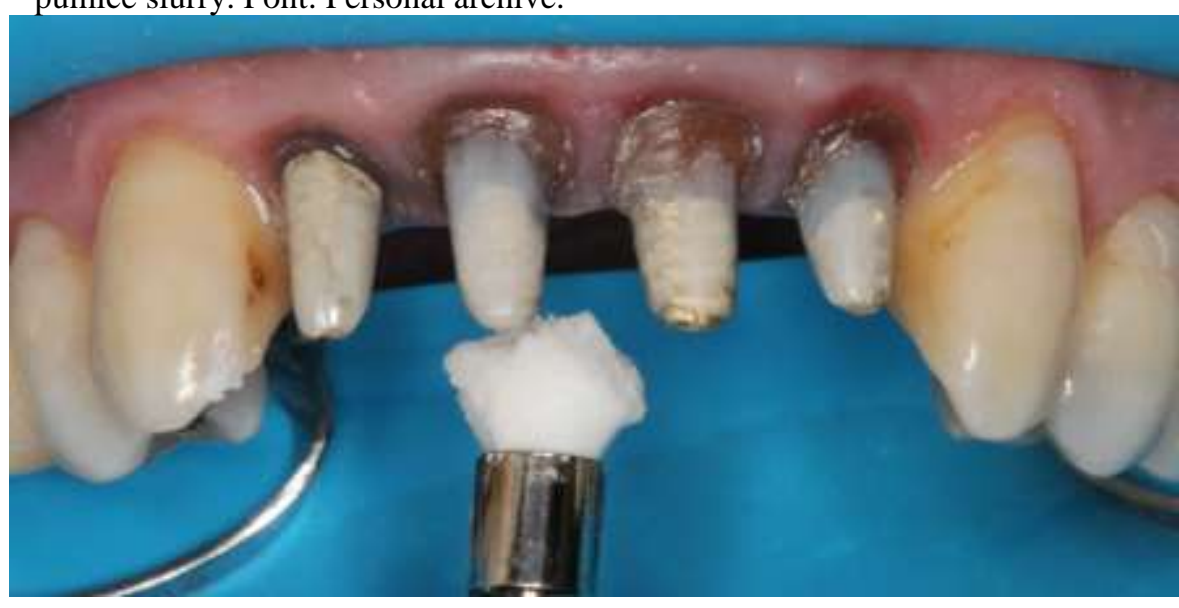

Source: Authors. 
Figure 9. A. $10 \%$ hydrofluoric acid etching of the crowns for $20 \mathrm{se}$; B. Silane coupling agent. Font: Personal archive.

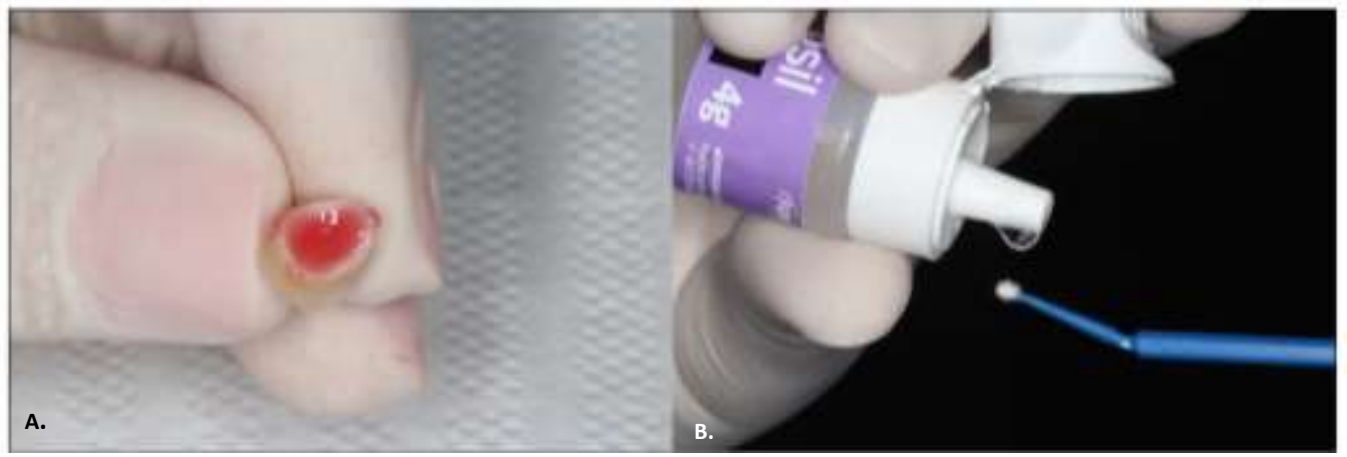

Source: Authors.

Cementation of the crowns was performed using a self-adhesive dual-cure resin cement (SeT PP, A1, SDI, Victoria, Australia) (Figure 10) associated to self-mixing tips, which allowed direct insertion of the cement into the crowns. After 1 min, cement excess was removed, and chemical setting time of the resin cement was allowed for 5 min. Subsequently, each face of the crowns was light activated for 60 seconds with a cordless LED unit (Radii Cal, SDI) (Figure 11). The patient was instricted in relation to care, maintenance, and hygiene.

Figure 10. A. Self-adhesive resin cement; B. Light-curing for $60 \mathrm{~s}$ on each aspect. Font: Personal archive.

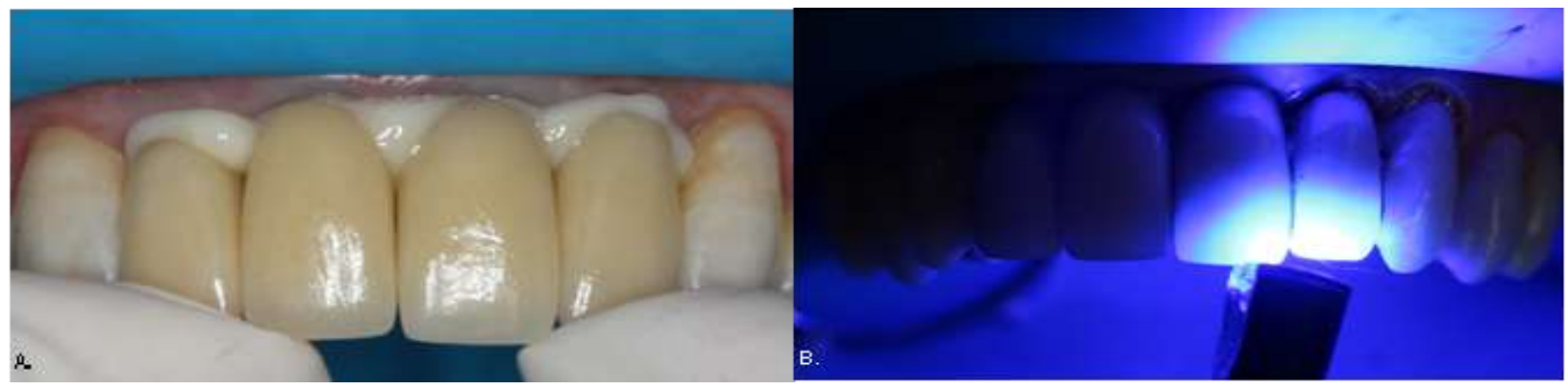

Source: Authors.

Figure 11. Adequate final aspect of the case after rehabilitation of teeth 12, 11, 21 and 22 with lithium disilicate glass-reinforced ceramic crowns. Font: Personal archive.

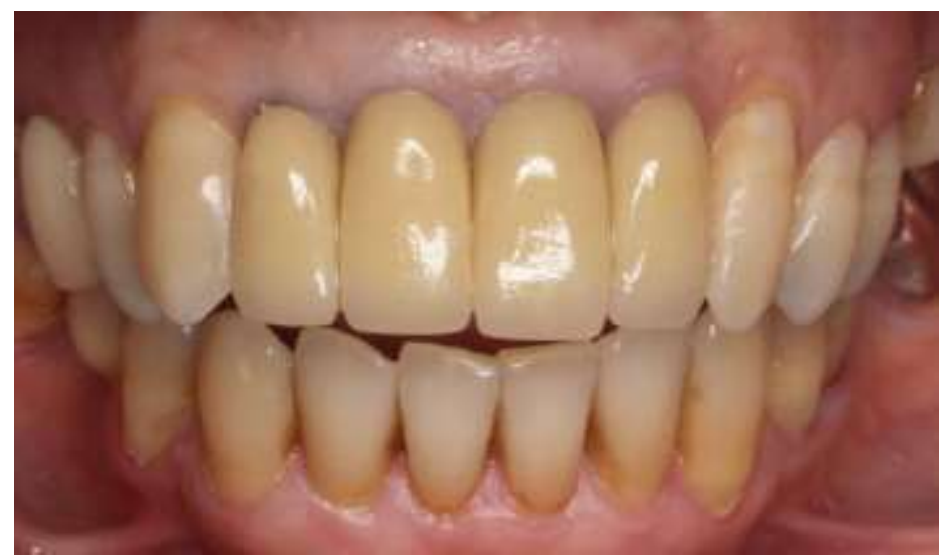

Source: Authors. 
After rehabilitation was completed, an occlusal splint was obtained. Due to the patient's occlusal imbalance and other external factors, she has reported orofacial pain and nocturnal bruxism. Initially, impressions of both arches were taken with alginate (Hydrogum V, Zhermack, Italy). Then, a Lucia's JIG was made of acrylic resin (Dencrilay, Dencril, Pirassununga, SP, Brasil) for deprogramming the proprioceptive memory and recording the centric relationship, allowing for stable accommodation of the condyles in the mandibular fossae. The interocclusal registration was performed with acrylic resin (Dencrilay, Dencril). And finally, the registration with the facebow was obtained for mounting the cast models on a semiadjustable articulator. After the occlusal splint was installed, the necessary adjustments were carried out to assure adequate occlusal balance and excursive mandibular movements. Lastly, final polishing of the occlusal splint was carried out (Figure $12)$.

Figure 12. Occlusal splint installed following oral rehabilitation. Font: Personal archive.

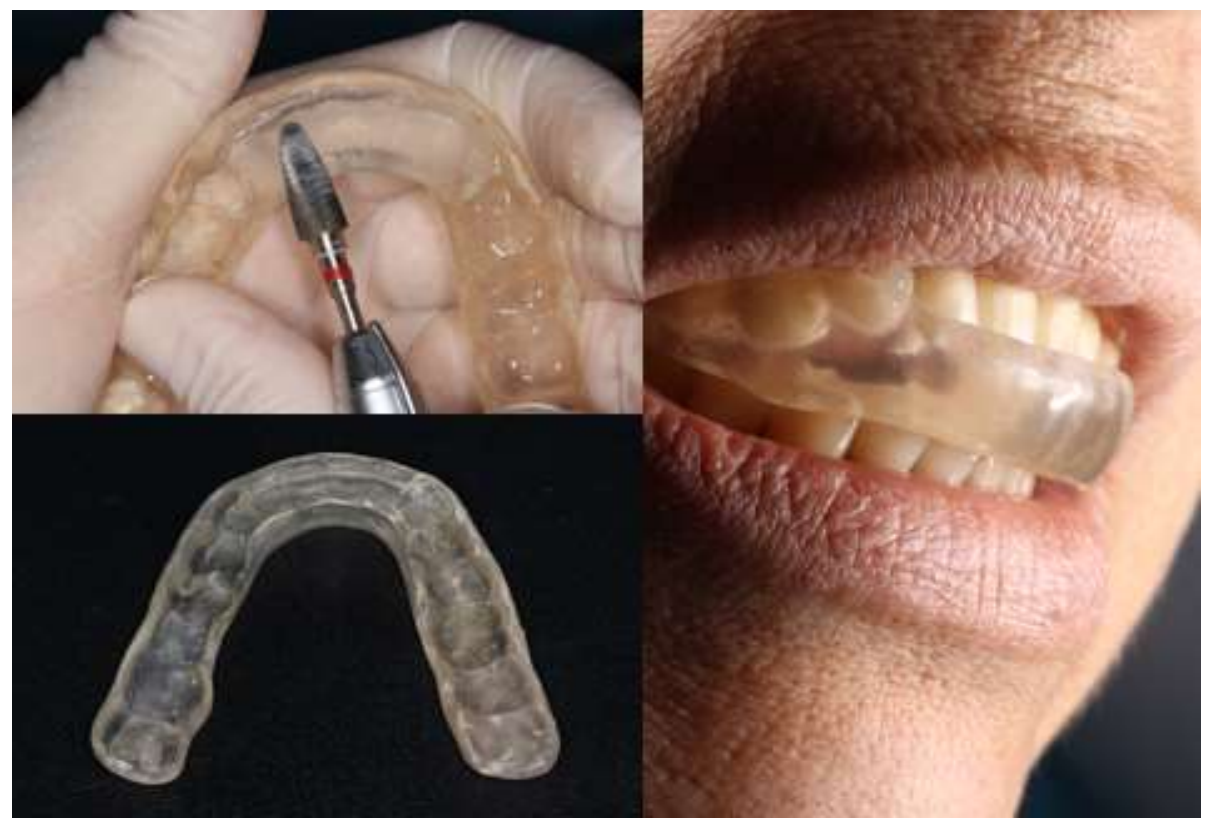

Source: Authors.

\section{Discussion}

Ceramics as a restorative material have been used in Dentistry for over two hundred years and lastly, this material has been widely used due to the high demand for esthetic restorations, concomitant with its great development in terms of physical properties. Among the available restorative materials, the aesthetic potential and biocompatibility of ceramics may be considered unique (Pagani, Miranda, \& Bottino, 2003). In this sense, ceramics have good structural, morphological and mechanical properties, in addition to high potential to biomimetic dental characteristics, such as: translucency, fluorescence, chemical stability, biocompatibility, high compressive strength, linear thermal expansion coefficient similar to tooth structure, thermal conductivity similar to dental tissues and color stability (Kreidler, 2008; Zarone et al., 2016).

In the case presented, a ceramic system reinforced by lithium disilicate crystals was chosen due to its versatility. This system emerged to improve the clinical performance of conventional feldspathic ceramics with respect to mechanical properties (Aguiar et al., 2016). Its glassy structure has needle-shaped crystals, arranged in an intertwined manner, favoring its high flexural strength and making crack propagation inside it more difficult (Kina, 2005; Carvalho et al., 2012). The longevity of lithium disilicate glass ceramics led this material to be recommended for several rehabilitations.

An anterior skeletal open bite as the presented by the patient in this case is a challenge, both for functional 
rehabilitation and for the esthetics of the restoration. There are several etiological factors related to this vertical malocclusion, including the presence of oral habits (Rijpstra \& Lisson, 2016). Treatment depends on several factors, such as the patient's age, concerns, and expectations. And for patients with permanent dentition at an advanced age, only surgical intervention can solve their vertical dimension combined with previous orthodontic treatment (Burford \& Noar, 2003; Maciel \& Leite, 2005). In some cases, the open bite can be resolved through elongated dental restorations, however, in the case described, the patient already has a narrow dental profile, which would leave the restored teeth longer than recommended (Ali et al., 2015; Bohner et al., 2017). Regarding the surgical intervention, this option was presented to the patient, who preferred not to undergo the procedure. The occlusal condition is directly related to the musculoskeletal system, so any change in the occlusal pattern may be directly related to orofacial pain and, in this specific case, the inability to perform the protrusive movement properly, overloads the muscle system and teeth later, causing possible consequences in the dental and periodontal tissues (Okeson, 2013). As a sign of occlusal derangement, posterior teeth present non-carious cervical lesions, together with a history of dental fractures during nocturnal bruxism.

It was decided to keep the cast posts, as their removal would bring a high risk of root fracture (Batista, 2019). Although the central and lateral incisors present a risk of fracture due to oblique forces, the installation of new cast posts was chosen because of the low remaining amount of ferrule and preserved root canal walls (Pegoraro et al., 2012; Minguini et al., 2014; Mendonça et al., 2017; Soares et al., 2018;). The use of opaque composite resin for masking the metallic core provides better adhesion between the preparation reminiscent and the ceramic crowns promoted by the silane. This agent provides adhesion between a material composed of reacting molecules on inorganic surfaces (ceramic) and organic surfaces (composite resin), thus managing to form a covalent bond between the two surfaces (Matinlinna \& Vallittu, 2007). A study by Volpato et al. (2009), showed that several light sources influence the translucency of the ceramic, and if there is a darkened dental substrate or the use of a metallic core, it is necessary to mask the darkened region, minimizing undesirable aesthetic effects in the final restoration.

The success of the restoration depends on several factors, including reliable impressions of the dental preparations. Correct gingival retraction for correct reproduction of the preparations is essential. The two techniques used in this case are widespread in clinical routine, with the use of unitary trays known as individual caps and the use of retractor cords in association with hemostatic agents (Zavanelli et al., 2016) to retract the soft periodontal tissues. The use of retractor cords is advantageous for controlling sulcular moisture at the time of impression, also improving the speed of the procedure (Fazekas et al., 2002; Zavanelli et al., 2016). However, even though the technique was first chosen among specialists in dental prostheses, there is great discussion in the literature regarding the trauma produced to the sulcular epithelium with the use of astringent solutions that this technique usually requires. The caps technique has the main advantage of not appling a chemical during impression, using only the mechanical method for gingival retraction, thus reducing the risk of trauma to the soft tissues. In addition, it is easy to handle and economic, as it requires little impression material to fill the cap. As a disadvantage, it is unable to control the humidity of the gingival sulcus (Guedes \& Machado, 2007; Pegoraro et al., 2013). The gingival profile of the patient in the case presented, is classified as thin, so it has priority indication for impressions using a cap; however, due to the daily practice, the first imporesson technique was performed with retractor cords. Subsequently, it was necessary to carry out new impressions using the caps technique, completing a reliable copy of all subgingival preparations (Mendes \& Pagani, 2001). Thus, using the two main impression techniques for fixed prosthodontics can be n3cessary in some situations, contributing to reliable results.

Self-adhesive resin cements present adequate mechanical properties as compared to conventional resin cements, in addition to dimensional stability and micromechanical adhesion (Gerth et al., 2006). With the advantage of improved tolerance to moisture and not reduced postoperative sensitivity (Mazioli et al., 2017). Lithium disilicate-based ceramics have a 
reasonable volume of vitreous matrix, which is acid-sensitive, which after silanization enables greater chemical adhesion to resin-based materials (Mair \& Padipatvuthikul, 2010). Mazioli et al. (2017), carried out a study, which analyzed the bond strength of different cements to lithium disilicate glass ceramics substrates. After microshear tests and analysis under optical microscopy, the authors observed that the conventional resin cement showed higher bond strength values, being the most suitable option for cementing lithium disilicate ceramics. However, the bond strength of the self-adhesive resin cements to dental ceramics is considered acceptable by the literature (Radovic et al., 2008). Additionally, the simplicity in the handling and clinical use of the self-adhesive resin cements is presented as a major advantage; therefore, it brings a lower incidence of technical errors in surface preparation. Thus, to obtain a good result, it is necessary to strictly follow the directions for preparation of the restorations and the correct indication of the resin cement.

\section{Conclusion}

The present clinical case report allows us to conclude that, in order to be successful in dental rehabilitation, it is important to re-establish esthetics with function. All steps for the elaboration of the prosthetic restorations have a direct relationship between them, which, when neglected, put the result of the treatment at risk. The realization of indirect restorations that respect the biological distance and return the desired esthetics to the patient are essential for the success of the treatments. The use of lithium disilicate glass-reinforced ceramis proved its versatility and favorable aesthetics, with good optical properties and biocompatibility. The application of a opaque resin composite for masking the metallic post, favoring the esthetic results and leading to a better substrate luting substrate for resin cements, improving adhesion between the ceramic restoration and dental preparation.

At the beginning of this case, the issue of performing orthognathic surgery to re-establish the present skeletal open bite was mentioned, which would improve occlusal stability. The surgical procedure would be helpful to reduce the overloading of the posterior teeth, allowing anterior guidance during the excursive movements, probably reducing the orofacial pain problems presented by the patient. However, it is important to take into consideration the patient's age and the entire process that she would go through before and after orthognathic surgery, with all the morbidity and expenses associated to the surgical procedure. The patient always should be aware of the limitations of each treatment planning option.

\section{References}

Aguiar, E. M. G., Rodrigues, R. B., Lopes, C. D. C. A., da Silveira Júnior, C. D., Soares, C. J., \& Novais, V. R. (2016). Diferentes sistemas cerâmicos na reabilitação oral: relato de caso clínico. Revista Odontológica do Brasil Central, 25(72).

Ali, J., Calamia, C., Magid, K. S., Calamia, J. R., \& Giannuzzi, N. J. (2015). An aesthetic and functional rehabilitation: a case study. Dental Clinics, 59(3), 547-557.

Amoroso, A. P., Ferreira, M. B., Torcato, L. B., Pellizzer, E. P., Mazaro, J. V. Q., \& Gennari Filho, H. (2012). Cerâmicas odontológicas: propriedades, indicações e considerações clínicas. Revista odontológica de Araçatuba, 19-25.

Andrade, A. D. O., Silva, I. V. D. S., Vasconcelos, M. G., \& Vasconcelos, R. G. (2017). Cerâmicas odontológicas: classificação, propriedades e considerações clínicas. Rev. Salusvita (Online), 1129-1152.

Anusavice, K. J. (2013). Phillips materiais dentários. Elsevier Brasil.

Batista, C. P. (2019). Influência dos protocolos ultrassônicos de remoção de núcleo metálico fundido no desenvolvimento de trincas e fraturas radiculares.

Bohner, L. O. L., Laganá, D. C., Zanardi, P. R., Sesma, N., \& Neto, P. T. (2017). Functional and aesthetic rehabilitation in patient with anterior open bite: a case report.

Brochu, J. F., \& El-Mowafy, O. (2002). Longevity and clinical performance of IPS-Empress ceramic restorations-a literature review. Journal-Canadian Dental Association, 68(4), 233-238.

Burford, D., \& Noar, J. H. (2003). The causes, diagnosis and treatment of anterior open bite. Dental update, 30(5), $235-241$.

Butt, K., Thanabalan, N., Ayub, K., \& Bourne, G. (2019). Demystifying Modern Dental Ceramics. Primary dental journal, 8(3), $28-33$. 
de Carvalho, R. L. A., de Faria, J. C. B., Carvalho, R. F., Cruz, F. L. G., Goyatá, F. R., \& Leite, F. P. P. (2012). Indicações, adaptação marginal e longevidade clínica de sistemas cerâmicos livre de metal: uma revisão da literatura. IJD. International Journal of Dentistry, 11(1), 55-65.

Conceição, E. N., \& Sphor, A. M. (2005). Fundamentos dos sistemas cerâmicos. Porto Alegre: Artmed.

Estrela, C. (2018). Metodologia científica: ciência, ensino, pesquisa. Artes Médicas.

Fazekas, A., Csempesz, F., Csabai, Z., \& Vag, J. (2002). Effects of pre-soaked retraction cords on the microcirculation of the human gingival margin. Operative dentistry, 27(4), 343-348.

Garcia, L. D. F. R., Consani, S., Cruz, P. C., \& Souza, F. D. C. P. P. D. (2011). Análise crítica do histórico e desenvolvimento das cerâmicas odontológicas. RGO. Revista Gaúcha de Odontologia (Online), 59, 67-73.

Gerth, H. U., Dammaschke, T., Züchner, H., \& Schäfer, E. (2006). Chemical analysis and bonding reaction of RelyX Unicem and Bifix composites—a comparative study. Dental Materials, 22(10), 934-941.

Gomes, E. A., Assunção, W. G., Rocha, E. P., \& Santos, P. H. (2008). Cerâmicas odontológicas: o estado atual. Cerâmica, 54(331), 319-325.

Guedes, C. G., \& Machado, C. E. P. (2007). Afastamento gengival: uma visão atual dos especialistas em prótese dentária do Distrito Federal. RGO, 55(4), 381-388.

Kang, S. H., Chang, J., \& Son, H. H. (2013). Flexural strength and microstructure of two lithium disilicate glass ceramics for CAD/CAM restoration in the dental clinic. Restorative dentistry \& endodontics, 38(3), 134.

Kassardjian, V., Varma, S., Andiappan, M., Creugers, N. H., \& Bartlett, D. (2016). A systematic review and meta analysis of the longevity of anterior and posterior all-ceramic crowns. Journal of dentistry, 55, 1-6.

Keerthana, S. V., Thulasiram, D., \& Kannan, D. (2020). Open bite: etiology, diagnosis and management. European Journal of Molecular \& Clinical Medicine, 7(4), 1753-1756.

Kina, S. (2005). Cerâmicas dentárias. Rev. dental press estét, 111-128.

Kreidler, M. A. D. M. (2008). Caracterização da influência do tipo de sinterização na composição química, resistência à flexão e dureza de blocos cerâmicos para CAD/CAM.

Lien, W., Roberts, H. W., Platt, J. A., Vandewalle, K. S., Hill, T. J., \& Chu, T. M. G. (2015). Microstructural evolution and physical behavior of a lithium disilicate glass-ceramic. Dental materials, 31(8), 928-940.

Maciel, C. T. V., \& Leite, I. C. G. (2005). Aspectos etiológicos da mordida aberta anterior e suas implicações nas funções orofaciais. Pró-Fono Revista de Atualização Científica, 17(3), 293-302.

Mair, L., \& Padipatvuthikul, P. (2010). Variables related to materials and preparing for bond strength testing irrespective of the test protocol. Dental materials, 26(2), e17-e23.

Martins, L. M., Lorenzoni, F. C., Farias, B. C., Lopes, L. D., Bonfante, G., \& Rubo, J. H. (2010). Comportamento biomecânico das cerâmicas odontológicas: revisão. Cerâmica, 56(338), 148-155.

Matinlinna, J. P., \& Vallittu, P. K. (2007). Bonding of resin composites to etchable ceramic surfaces-an insight review of the chemical aspects on surface conditioning. Journal of Oral Rehabilitation, 34(8), 622-630.

Mazioli, C. G., Peçanha, M. M., Daroz, L. G. D., Araújo Siqueira, C., \& Fraga, M. A. A. (2017). Resistência de união de diferentes cimentos resinosos a cerâmica à base de dissilicato de lítio. Revista de Odontologia da UNESP, 46(3), 174-178.

Mendes, E. M., \& Pagani, C. (2001). Considerações sobre os métodos de afastamento gengival. JBC j. bras. clin. estet. odontol, $137-42$.

Mendonça, C. G., Almeida, J. R. V. D., Takeshita, W. M., Martins, F., \& Paixão, M. S. (2017). Radiographic analysis of 1000 cast posts in Sergipe state, Brazil. Revista de Odontologia da UNESP, 46(5), 255-260.

Minguini, M. E., Mantovani, M. B., Lolli, L. F., Silva, C. O., Progiante, P., \& Marson, F. C. (2014). Estudo clínico de pinos intrarradiculares diretos e indiretos em região anterior. Revista Uningá Review, 20(1).

Moraes, J. R. (2010). Resistência de união entre cerâmica à base de dissilicato e cimentos resinosos: efeito do tratamento de superfície da cerâmica, do sistema de cimentação e da aplicação de adesivo.

Okeson, J. P. (2013). Tratamento Das Desordens Temporomandibulares E. Elsevier Brasil.

Pagani, C., Miranda, C. B., \& Bottino, M. C. (2003). Avaliação da tenacidade à fratura de diferentes sistemas cerâmicos. Journal of Applied Oral Science, 11(1), 69-75.

Pegoraro, L. F., do Valle, A. L., de Araujo, C. D. R. P., Bonfante, G., \& Conti, P. C. R. (2013). Prótese Fixa: bases para o planejamento em reabilitação oral. Artes Médicas Editora.

Proffit, W. R. (2002). Ortodontia contemporânea. 3. ed. Rio de Janeiro: Guanabara Koogan.

Radovic, I., Monticelli, F., Goracci, C., Vulicevic, Z. R., \& Ferrari, M. (2008). Self-adhesive resin cements: a literature review. Journal of Adhesive Dentistry, $10(4)$. 
Raposo, L. H. A., Davi, L. R., Simamoto-Jr, P. C., Neves, F. D., Soares, P. V., Simamoto, V. R. N., ... \& Borella, P. (2014). Restaurações totalmente cerâmicas: características, aplicações clínicas e longevidade. Associação Brasileira de Odontologia. Pinto T., Verri F.R., Carvalho O.B., JR, organizadores. PRO-ODONTO PRÓTESE E DENTÍSTICA Programa de Atualização em Prótese Odontológica e Dentística: Ciclo, 6.

Rijpstra, C., \& Lisson, J. A. (2016). Etiology of anterior open bite: a review. Journal of Orofacial Orthopedics/Fortschritte der Kieferorthopädie, 77(4), 281286.

Silva, L. H. D., Lima, E. D., Miranda, R. B. D. P., Favero, S. S., Lohbauer, U., \& Cesar, P. F. (2017). Dental ceramics: a review of new materials and processing methods. Brazilian oral research, 31.

Soares, D. N. S., \& Sant, L. L. P. (2018). Estudo Comparativo entre Pino de Fibra de Vidro e Pino Metálico Fundido: Uma Revisão de Literatura. ID on line Revista de psicologia, 12(42), 996-1005.

Song, X. F., Ren, H. T., \& Yin, L. (2016). Machinability of lithium disilicate glass ceramic in in vitro dental diamond bur adjusting process. Journal of the mechanical behavior of biomedical materials, 53, 78-92.

Oliveira, W. D. F., Popoff, D. A. V., \& Júnior, A. R. S. (2013). Restaurações estéticas com dissilicato de lítio: relato de caso clínico. Buenos Aires, EFDeportes. com Revista Digital, 18, 179.

Zarone, F., Ferrari, M., Mangano, F. G., Leone, R., \& Sorrentino, R. (2016). "Digitally oriented materials": focus on lithium disilicate ceramics. International journal of dentistry, 2016.

Zavanelli, R. A., Zavanelli, A. C., Magalhães, J. B., de Paula, W. N., Cardoso, L. C., Lima, G. R. B., ... \& Mazaro, J. V. Q. (2016). Técnicas convencionais e atuais de moldagem em próteses fixas. PRO-Odonto Protése e Dentística Programa de Atualização em Prótese Odontológica e Dentística: Artmed Panamericana, 2(7), 119-76.

Zhang, H., Sun, Y., Guo, J., Meng, M., He, L., Tay, F. R., \& Zhang, S. (2019). The effect of food medium on the wear behaviour of veneering porcelain: An in vitro study using the three-body abrasion mode. Journal of dentistry, 83, 87-94.

Volpato, C. Â. M., Monteiro Jr, S., de Andrada, M. C., Fredel, M. C., \& Petter, C. O. (2009). Optical influence of the type of illuminant, substrates and thickness of ceramic materials. Dental materials, 25(1), 87-93.

Willard, A., \& Chu, T. M. G. (2018). The science and application of IPS e. Max dental ceramic. The Kaohsiung journal of medical sciences, 34(4), 238-242. 